\title{
Hindu Religious Literature and Cultural Transformation in Manipur
}

\author{
Dr. Ch. Sarajubala Devi* \\ Associate professor, NERIE, University in Umiam, Meghalaya, India \\ *Corresponding Author \\ Dr. Ch. Sarajubala Devi
}

\section{Article History}

Received: 08.02.2021

Accepted: 15.02 .2021

Published: 19.02.2021

\begin{abstract}
Hinduism which emerged in the $18^{\text {th }}$ century is the dominant religion of the Meiteis in the state of Manipur. It was accepted as a state religion in 1714 AD during the reign of king Garibaniwaj. There was a systematic process of induction of the religion in the minds of the earlier Non Hindu people of the state. Brahmins from the neighbhouring states were deployed in the court for every possible rites and rituals performed in state. In almost all the possible localities a Brahmin was deployed with patronization either from the king or by the locality. These Brahmins and other Manipuri scholars compiled and translated various Hindu scriptures written in Sanskrit and in Bengali into Manipuri for easy access by the mass. It is during this period that Sanskrit, Bengali and Hindi elements were systematically incorporated in culture, religion, polity and language. As a result of this $18^{\text {th }}$ century and early $19^{\text {th }}$ century Manipuri literature has marked influence of the Sanskrit and Bengali literatures. A number of religious books was translated and adapted versions of many such literature emerged in this period. Age old umanglais (the sylvan deities) of Meiteis were very tactfully equated with the Hindu Gods. The ceaseless indoctrination into a new faith and culture was made successful through the cultural projects of LairikThiba_haiba (narration and translation of scriptures) and Waree leeba religious story telling) - mass education of Meiteis in Hindu scriptures viz. the Mahabharata and the Ramayana in the Mandapas (the community halls) and establishment of children's dance drama the GouraLila and women's dance drama the Rasa Lila etc. The paper will look into the systemic process of proselytisation and popularization of Hinduism through the tactful use of religious literature, without which the culture of Hinduism would never have been imbibed at all by the masses in Manipur.
\end{abstract}

Keywords: Hinduisation, waree leeba, lairik thiba-haiba, literature.

\section{INTRODUCTION}

The present state of Manipur is the ancient kingdom of Meiteis and several hill tribes. Meiteis are the predominant group in the state and they are mostly Hindus (41.39\%, 2011 census). Some Meiteis follows Sanamahism (the pre Hindu religion, 7.78\%, 2011census) and there is a strong revivalist movement manifested both in language and the social life of the Meiteis in the state. Manipuri is the mother tongue of the Meitei community and it is locally known as Meiteilon. Several other speakers of this language live in some parts of the bordering countries like Myanmar, Bangladesh, and other Indian states like Assam and Tripura. It is also lingua franca of more than 35 ethnic communities in the state.

According to various Linguists, Manipuri belongs to the Tibeto-Burman sub-group of Sino-Titan languages. According to Grierson [1], Manipuri is a link language between the Kuki-Chin languages and the Kachin languages. Shafer [2,3] included Manipuri language under a separate branch called Meithei, which is placed under the Kukish section of his Burmic division of Tibeto-Burman. Benedict [4] classified Manipuri in the Kuki-Naga sub-group of the Kachin group of the Tibeto-Burman.

Manipuri language occupies a distinct position in the literature of North East India. It has its writing system with its own script known as Meitei Mayek (the script of the Meiteis). And Manipuri is the first Tibeto-Burman language of India to have been included in the Eight Schedule of Indian Constitution by the $71^{\text {st }}$ Amendment on $20^{\text {th }}$ August 1992 . The history of Manipur shows that Manipuri or Meiteilon is a direct descendent of the conglomeration of Tibeto-Burman

Copyright (C) 2021 The Author(s): This is an open-access article distributed under the terms of the Creative Commons Attribution 4.0 International License (CC BY-NC 4.0) which permits unrestricted use, distribution, and reproduction in any medium for noncommercial use provided the original author and source are credited. 
dialects of seven Meitei salais (clans) and it has been influenced and enriched by Indo-Aryan languages of Sanskrit origin in the early times and later by English. The influence of Sanskrit in Manipuri is the result of their long contact with the people from mainland India during the period of Hinduisation or Sanskritization which started from the early part of $17^{\text {th }}$ Century A.D. The influence of English in Manipuri is due to long British colonialism in Manipur from 1891-1947, and from the present education system prevalent in the state.

Before the advent of the Hinduism in the state there were predominance of the Umanglais (the sylvan deities) and the roles of Maiba and Maibi (priest and priestess) were significant. Festivals were observed for the state as a whole and also there were some significant festivals that centred on the royalty.

\section{Hinduisation and Emergences of Hindu Literature in Manipur}

Three different schools of Hinduism [5] entered to Manipur valley in different times had certain impacts in the cultural life of the then animistic Meitei society. The early school Nimbarka was unable to give a larger impact in the society, it was the two following schools of Hinduism, the Ramandi and the Cheiteina school that has changed the entire religious life of the Meiteis in Manipur. Hinduism was accepted as the state religion in 1714 A.D. when king Garibaniwaz (1709-1748) enforced it on all his subjects. It was after this new state religion that the state had closer contact, matrimonial alliance's military relationship with the Hindu Kings of Ahom kingdom of Assam and other neighbouring kingdoms of Tripura, Cooch-Bihar, and Sylhet etc. [6]. It is during the reign of King Bhagyachanrda (1759-1798), the older school of Ramandii was replaced by Chaiteinya, which introduced Radha and Krishna as the important God and Goddess and the introduction of Sankritana and Ras leela.

The impact of Hinduism in the general mass started from king Charairongba (1698-1709), his son king Garibniwaz (1709-1748) made it a state religion , their successors like king Bhagyachandra was a devotee of Govindaji, king Gambhir Singh (1821-1834) and king Chandrakriti (1850-1886) did a lot for the development, establishment and the popularisation of the religion to the mass. Of course it was due to patronisation of the mentioned kings that Hinduism can manifest in every act of a Meitei Hindu. King Bhagyachandras' Ras Leela [ $\left.{ }^{\mathrm{i}}\right]$, which is a synthesis of traditional Meitei dance forms in a new platform made the Meiteis dance form known to the Indian subcontinent and this Ras Leela has ultimately became one of the classical dance forms of India. Important Hindu festivals like Rath Jatra, Gostha Ashtami were introduced by Gambhir Singh During the reign of these kings' various processes of assimilation and adoption of various Hindu rituals were visible as well as there was a marked increase of Hindu religious texts. With the royal patronage many religious texts were translated as well as adapted with local flavour. These religious texts could give a profound impact on the masses as they were not confined to a few but made public by making the process of Lairik Thiba Haiba, Waree Leeba, Gaura Lila, Ras Lila etc. Though these ritualistic functions were celebrated initially with the royal patronage later it became a part of the Metiei society. The Hindu religious text which emerged with local flavour served a strong medium through which complex philosophy was internalised by the masses.

The adoption of Hinduism as the state religion brought about various forms of structural changes in the Meitei society. It was during the reign of King Garibniwaj, that the seven clans of Meiteis were equated with the Hindu Gotras, this very act in long run made the people feel a kind of age long tradition, even today despite the various movements of revivalism, at the time of rituals it is still prominent to use the Hindu Gotras instead of one's own lineage which is familiar to the person. The process of Hinduisation continues still and reached the stage of equalisation and consequent identification of the Meitei Gods with the Hindu Gods examples being Pakhangba as Lord Vishnu, Nongpok ningthou as Shiva and Panthoibi as Durga etc. [7]. Rituals related to life of the Meteis also replaced with the Hindu equivalents such as Swasti Puja for Ipan Thaba, Subha Bibhaha for Luhongba (Marriage) Asthi Chadal for Mangani Leihun (a ritual on the $5^{\text {th }}$ day of death), Shardha for Lanna Thouram (a rite of the death), etc. Moreover, most of the ancient Meitei festivals were replaced or associated with the Hindu festivals. Not only were these, in order to intensify the process of Sanskritisation, new Sanskrit names given to the ruling kings. Sankritans and Ras Lila were profound aspect of Hinduisation process, which was accepted widely. These very processes which were planned and well-engineered speed up the process of acceptance of the new religion [7]. The entire process of cultural adoption and assimilation is summarized by S.K. Chatterji [8] as 'Manipuri Hinduism gradually became a synthesis of the old legends and traditions, its social customs and usage, and its priests and ceremonials and of Brahhmanical Hinduism with its special worship of Radha and Krishna.'

As a result of this cultural transformation, a marked influence of the Sanskrit and Bengali literatures is visible in Manipuri literature of the $18^{\text {th }}$ Century. Leithak Leikharon, Thawanthaba khongjanglon and a number of other books during that period show the impact of Sanskrit and Bengali on Manipuri literature. Between 1717A.D. and 1737 A.D. some Parvas of the Mahabharata had been translated into Manipuri for the first time. Some cantos of the Ramayana were also translated during the period between 1727 A.D. and 1748 A.D. Translations of different works are largely attributed to Angom Gopi, a poet of considerable ability. Volumes of such translation beautifully copied, and they were 
not only kept in the royal Loishang (office of the king) but were available to men who had a literary induce to read them [9].

King Bhaigyachandra was one of the strongest proponents of Hinduism in Manipur; himself a devotee of Govindaji initiated the Ras Lila. From 1776 A.D, he started reorganizing the whole country including religious institutions, constructed new temples with the idols of Hindu deities like Shri Govindaji, Madan Mohan and Gopinath. The first Ras Lila was dedicated to the Sri Govindaji on its installation in 1779.

During the reign of king Bhaigyachandra, Manipuri scholars started to adopt Bengali and Sanskrit words as a medium of their literary works in most cases [9]. The Puranas were expounded in Manipuri and heroic tales were created by the poets to fortify the converts psychologically. Many religious books, scriptures were copied, translated and written during his time. The king himself, his daughter Sija Lairoibi and son Nabanada compose many verses praising the Hindu Gods [10]. It is believed that the book called Govinda Sangit Lila Vilas articulating Manipuri dance in Sanskrit is written by the King himself [11]. One of the important literary texts of his reign is the translation of Virat Parva of Mahabharata in Manipuri language by prince Nabanada 1780. N. Khelchandra 1969 gave a complete list of literary works produced during king Bhagyachnadra's time-Asyamedha by Longjam Parsuram, Astakala Lila and Mathura Virah by Yumkhaibam Chandra Singh. Chingthangkhomba Vrindavana Chatpa and Chingthangkhomba Ganga Chatpa, Janmenjaya Sapa Yojna is some of the important writings produced during Bhaigyachandra's time. Most of the words used in every sentence have Sanskrit and Manipuri mixture [11]. All these writings in Manipuri language influence the mass and slowly people started accepting these stories as part of everyday discussions and dialogues.

The tradition of translation adaptation and writings of Hinduism continues and Manipuri literature was enriched with many loanwords from Sanskrit and Bengali. Hindu religious epics like Bhagavata Purana, Vishnu Purana, Smritis Sastra, Geetgovinda, Chaitanya Charitramantra, Vaishnapadavali etc. Were translated into Manipuri in 19 century by Manipuri Vishnavas. The source language of these translation works were either the Sanskrit or the Bengali. This phenomenon has resulted to the preference of code mixed with Bengali or Sanskrit words. The practice of translation, adaptation and rendering of Hindu religious texts continued in the Medieval Manipuri (1750-1900AD) Literature. The literature of this stage is enriched with the Sankritan literature. The Bhakti Sangeet which was popular in Bengal in that time has influenced Manipuri literature and inspired lakhs of Manipuri Vaishnavas [12]. King Charairongba patronized devotional singing or Kirtana the theme of which is derived from Padavalis and Hlas which was popular in Bengal, The Manipuris make Sankirtan part of their lives. The sixty- four Bhakti Rasa of Bengal School was sung and danced in sixtyfour sessions at the palace during Chandrakriti's reign [13]. These are all exemplars on how the hinduisation process was speeded up with the royal patronage. The traditions became a usual practice, became popular and slowly it became a part of Hindu Meitei life.

\section{The emergence of Waree leeba and Lairik thiba-Haiba tradition}

The Waree Leeba (story telling) and the Lairik Thiba-Haiba (recitation and its Manipuri translation of the religious text) traditions may be considered as one of the biggest project taken up by the Hinduised state of Manipur for the popularisation of Hinduism. Over the years quite a good number of literatures of Hindu religion were accessible to the royal family, to the brahmins and to the Meitei scholars who took toil to learn the literature. It is said that the court scholars of King Garibniwaz began translating the epics such as Ramayana and Mahabharata into Meiteilon and soon began enacting episodes or stories to popularize the new faith. Thus, Wari-Leeba is a type of oral recitation that 'paints pictures through words' and is based mainly on episodes of the Mahabharata [14]. Renowned historian of Manipur E. Nilkanta is, however, of the view that tradition of Wari-Leeba was introduced during the reign of King Jai Singha (also known as Rajarshi Bhagyachandra), as a gift from the culture of Assam. Jayaram Sharma (also known as Jeeuram Thakur) from Assam narrated the tenth chapter of Bhagavatam for the first time. It is said that Sharma arrived in Manipur in the year 1776 A.D and reinvented the tradition of storytelling. In course of time, this intensely dramatic art of narration took up themes from Ramayana, Mahabharata and other Puranas [15]. According to Sadananda M. [16] the stories of the Ramayana and the Mahabharata have played a significant role in the process of sanskritisation among the Meiteis of Manipur as the people became acquainted with the epics.

Konthoujam Kunjo Singh, an exponent of the Waree-Leeba tradition, opines that this narrative form of storytelling enables common man to understand the concepts of Rajneeti (politics) and Dharmaneeti (ethics) inherent in epics like the Ramayana and the Mahabharata. Much like the Paanchali or Vrata-Katha tradition observed by the Bengali community, it is believed that if one listens to the Waree with dedication and respect towards the narration, all sins of the previous birth would be washed off.

It is also believed that the narrator also is also a devotee offering nine forms of Bhakti to the Lord. It is essential to be great performer that one can fill the heart of the audience with the emotions. The Waree Leeba performance do not have any particular occasion, it can be performed in events relating to rites de passage, religious and seasonal festivals, 
social and communal gatherings [16]. Various rituals are observed in the Waree Leeba as the act is considered auspicious.

\section{Lairik Thiba haiba}

The tradition of Lairik Haiba Thiba is also one of the important media through which the vaishnavite tradition goes deep into the heart of the people. In this art form the Sanskrit slokas of Lakshman Digvijaya and or the Gitbobinda of Jaydeva is read out by the Lairik Thiba mee (the first performer) as it is with the proper rhythm after which the meaning in Manipuri is stated by the another counterpart Lairik Haiba mee (the second performer), in this process the meaning of the text goes deep into the minds of the people. This traditional narrative art is said to be started from the Vasant Panchami of 1794 during the reign of king Garibaniwaj. The first persons to start with this art in Manipur are Khundrakpam Damusingh as Lairik Thiba and Pukhrambam Chaobasingh as Lairik Haiba. Though presently the art is limited in certain restricted spheres, in the pre-World War II Manipur the tradition was very popular. Compared to waree leeba this art form has limited circulation as the audience is elderly people. In the present day the tradition is practiced in the Langban (a Meitei lunar month) in mandops (a community ritual place maintained mainly by Brahmins) of many localities.

One of the interesting developments in this almost dying tradition is that the Lairik Thiba Haiba tradition in a modified form has become a ritual which could be performed by a family for their needs based on the belief system. When a family is suffering from miseries or someone has been sick for quite some time there is a tradition of calling a Brahmin to perform Lairik Haiba mainly Gopal Sahashranam. It is believed that by chanting the different names of Sri Krishna will help the family. Even the act of reciting Gopal Sahshranam is done for a person in the dead bed with the belief that the departing soul could become a real devotee in the foot of the lord.

Both the art forms act as a medium of mass education of the public in the Viahnavite literature, its religious beliefs, philosophies and the associated culture. Masses understood the philosophy and the values imparted, in other words the culture was accepted and became a part of Meitei way of life in due course of time.

\section{The impact of Waree Leeba and Lairik Thiba- Haiba}

As has been discussed the process or the act of Waree Leeba has a profound impact on the general mass. It is through the Wari Leeba tradition that the general public are aware of the religious literatures like Mahabharata, Ramayana etc. not through the reading of the text written in whichever language Manipuri or any other. Groups of elderly men and women called a Wari Leeba mi /Wariroi (the story teller) on the occasions of Swasti puja, Nahutpa (ear boring ceremony) Phiroi (the final rite of the deceased) etc. and also for any lag season like Langban Waree Taba (listening to the stories in latter part of August and early September, during which the agricultural activities are little relaxed), Durga puja etc. in almost every locality in the mandabs. Through this process of Wari Leeba along with all the rituals involved in it became a part and parcel of the social life of the Meities. Each one was aware of the Hindu tales along with the value as well as the religious flavour. Till date none of the Meitei traditional literatures could reach far and wide as is done in this cultural project.

\section{CONCLUSION}

Hinduism which was a religion adopted by the Meitei kings in the 18 century, became a religion of the mass despite strong oppositions from the traditional scholars who have profound influence to the mass (the Maichous) and the common people. Achieving this feat was not easy, there were a long process of social engineering, there were lots of literature translation, adaptation, adoption, rewriting of the religious scriptures to make it accessible to the common people. Different forms of adjustments, indoctrinations kept going. Indoctrination to new faith and culture was achieved largely through the cultural project of Lairik Thiba-Haiba and Waree Leeba which had common people as audience. It was made believed that becoming a real Hindu who observed rites and rituals as prescribed by the scriptures and religious text is the only way to live a holy and pious life. Rituals with Hindu faith were strictly observed and many faiths were popularised by various forms of cultural festivals patronised by the royal family. The agents of the new faith, the Brahmins under the royal patronage successfully carried out their mission of proselytisation and popularized Hinduism, without whom the culture of Hinduism perhaps would ever have been imbibed at all by the masses in Manipur.

The conversion of Manipuri to Hinduism had enormous implication for their culture, literature and language. Medieval Manipuri literature had a lot of Hindi, Bengali and Sanskrit words; of course this very process has made the Manipuri language enriched with lots of texts, later on also many scholars even translated modern Bengali literature adding a new flavour to a developing language. The translated and or the adapted Hindu literature which initially had a limited circulation was made available to the masses not through the literature test itself but the rendition of it in the form of Waree Leeba and Lairik Thiba Haiba traditions. 


\section{REFERENCES}

1. Grierson, G.A. (1904). Kuki-Chin Group, Linguistic Survey of India, Vol. III, Part. III, London 1904.

2. Shafer, R. (1955). Classification of the Sino-Tibetan languages. Word, 11(1), 94-111.

3. Shafer, M. W., \& Suits, J. C. (1966). Preparation and Faraday rotation of divalent europium glasses. Journal of the American Ceramic Society, 49(5), 261-264.

4. Benedict, B. P. K., Benedict, P. K., \& Matisoff, J. A. (1972). Sino-Tibetan: a conspectus (No. 2). CUP Archive.

5. Singh, K.B. (1963). "Manipur Vaishnavism:A Sociological Interpretation", Sociological Bulletin Vol-XII, September, Bombay.

6. Vijaylakshmi, B. (1998). Politics, Society and Cosmology in India's North-East, OxfordUniversity Press, Delhi,

7. Singh, Kh. Bijoykumar. (2013). 'Craft of Hinduism and State formation in Pre- modern Manipur' in H. Sudhir(ed.), Social History of Manipur, New Delhi: Sunmarg Publishers \&Distributors, p. 80.

8. Chatterjee, S.K. (1979). 'Linguistic Situation in States of Eastern Zone', Souvenir of the Cultural Conference of Eastern India, Purbha Bharat Sanskrit Sammelan, Culcutta.

9. Ibungohal, L. (1987). Introduction to Manipur.

10. Khelchandra, N. Singh. (1969). Ariba Manipuri Sahityagi Itihas, Imphal.

11. Yumjao Singh, W. (1966). An Early History of Manipur.

12. Jhaveri, A. S., \& Sharma, M. M. (1967). Kinetics of absorption of oxygen in aqueous solutions of cuprous chloride. Chemical Engineering Science, 22(1), 1-6.

13. Nath, M. C. (1943). Investigations on the new antidiabetic principle (amellin) occurring in nature. 1. Studies on some of its biochemical properties. Annals of Biochemistry and experimental Medicine, 3, 55-62.

14. Dharwadker, A., \& Tevet, J. (2009). The graph isomorphism algorithm. Proceedings of the Structure Semiotics Research Group.

15. Ramaswami, S. N., Flynn, E. J., \& Nilakanta, S. (1993). Performance implications of congruence between productmarket strategy and marketing structure: an exploratory investigation. Journal of Strategic Marketing, 1(2), 71-92.

16. Sadananda, M. (2015). 'Introductory Remark' Souvenir, 'A Seven Day Festival on Waree Leeba' All Manipur Waree Leeba Association \& Research Centre, Imphal.

${ }^{\mathrm{i}}$ Ras Lila was first offered to the lord Govindajee in 1779.

CITATION: Ch. Sarajubala Devi (2021). Hindu Religious Literature and Cultural Transformation in Manipur. South Asian Res J Art Lang Lit, 3(1): 13-17. 